\title{
Rapid, minimally invasive adult voluntary male circumcision: A randomised trial
}

\author{
P S Millard, ${ }^{1,2} \mathrm{MD}, \mathrm{PhD} ; \mathrm{H}$ R Wilson, ${ }^{1} \mathrm{BA} ; \mathrm{P}$ J Veldkamp, ${ }^{2} \mathrm{MD} ; \mathbf{N}$ Sitoe, ${ }^{1} \mathrm{MD}$ \\ 'Catholic University of Mozambique, Beira, Mozambique \\ ${ }^{2}$ Division of Infectious Diseases, Department of Medicine, University of Pittsburgh, Pennsylvania, USA
}

Corresponding author: P S Millard (pmillard@mac.com)

\begin{abstract}
Background. Voluntary medical male circumcision (VMMC) is a priority HIV preventive intervention. To facilitate male circumcision scaleup, the World Health Organization is actively seeking circumcision techniques that are quicker, easier, and safer than open surgical methods. Objective. To compare conventional open surgical circumcision with suturing with a minimally invasive technique using the Gomco circumcision clamp plus tissue adhesive.

Methods. We conducted a non-blinded randomised controlled trial comprising 200 male volunteers $>18$ years of age, seen at the outpatient university teaching clinic of the Catholic University of Mozambique. We compared two interventions - open surgical circumcision with suturing v. Gomco instrument plus tissue adhesive. Our primary outcome was intraoperative time and our secondary outcomes included: ease of performance, post-operative pain, adverse events, time to healing, patient satisfaction and cosmetic result.

Results. The intraoperative time was less with the Gomco/tissue adhesive technique (mean 12.8 min v. 22.5 min; $p<0.001$ ). Adverse events were similar except that wound disruption was greater in the Gomco/tissue adhesive group, with no difference in wound healing at 4 weeks. Levels of satisfaction were high in both groups. The cosmetic result was superior in the Gomco/tissue adhesive group.

Conclusions. This study has important implications for the scale-up of VMMC services. Removing the foreskin with the Gomco instrument and sealing the wound with cyanoacrylate tissue adhesive in adults is quicker, is an easier technique to learn, and is potentially safer than open surgical VMMC. A disposable plastic, Gomco-like device should be produced and evaluated for use in resource-limited settings.
\end{abstract}

S Afr Med J 2013;103(10):736-742. DOI:10.7196/SAMJ.6856

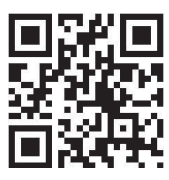

Numerous observational studies and three large randomised controlled trials conducted in Africa show that male circumcision reduces female-to-male transmission of HIV by $50-60 \%{ }^{[1]}$ as a result of which many sub-Saharan (SSA) countries are currently scaling up male circumcision programmes. ${ }^{[-4]}$ Male circumcision is a priority preventive intervention for the World Health Organization $(\mathrm{WHO})^{[5]}$ and the US President's Emergency Plan for AIDS Relief (PEPFAR). ${ }^{[3]}$

The ideal time to perform circumcision is in the newborn period, when it can be done with local anaesthetic, does not require sutures and is very safe. ${ }^{[6]}$ However, newborn circumcision is generally not practised in SSA and the challenge is to develop simple, safe and minimally traumatic techniques for circumcising boys and men.

Few studies have compared voluntary medical male circumcision (VMMC) techniques for ease of performance, safety and patient satisfaction. The WHO, in the Manual for Male Circumcision under Local Anaesthesia, describes only open surgical techniques which involve exposure of subcutaneous tissues and suturing for both haemostasis and skin closure. ${ }^{[7]}$

Open surgical techniques require good surgical skills and minor complications are common under the programmatic conditions existing in Africa ${ }^{[8]}$ Complication rates are related to the experience and other characteristics of the health provider. Studies of open surgical circumcision techniques have revealed shortcomings in practitioner knowledge and training. ${ }^{[9,10]}$

Given the drawbacks of open surgical circumcision, the WHO is seeking research on circumcision methods that '(i) would make VMMC safer, easier, and quicker; (ii) would have more rapid healing than current methods and/or might entail less risk of HIV transmission in the post-operative period; (iii) could be performed safely by healthcare providers with a minimal level of training; and (iv) would be cost-effective compared to standard surgical methods for male circumcision scale up. ${ }^{\text {[11] }}$

\section{Objective}

To compare conventional open surgical circumcision with suturing with a minimally invasive technique using the Gomco circumcision clamp plus tissue adhesive. We hypothesised that the new technique would prove superior to open surgical VMMC with regard to intraoperative time and ease of performance, and have similar adverse events.

\section{Methods \\ Trial design}

This was a single-centre non-blinded randomised controlled trial with allocation in balanced blocks of 10 to ensure equal sample size in each of the two groups. A study staff member who was not involved in the surgeries allocated participants in balanced blocks of 10 using a random number table. The slip of paper with the group assignment was folded and placed in sealed, opaque envelopes. Each envelope was opened only at the time of surgery.

The University of Pittsburgh Institutional Review Board and the National Committee of Bioethics of the Mozambique Ministry of Health approved the study. All subjects gave informed consent. Clinical researchers from the University of Pittsburgh comprised the Data Monitoring Committee. The study took place between 30 October 2012 and 2 March 2013.

\section{Participants}

Healthy uncircumcised men $>18$ years of age were eligible for the study. Participants were recruited via a poster at the medical school in Beira 
Mozambique. Exclusion criteria were: concurrent illness, history of bleeding disorder, past reaction to local anaesthetic, infection and penile abnormality (which would complicate circumcision). Men with phimosis were excluded from the study, but men who had a scarred frenulum - a common condition that can be easily corrected at circumcision - were included.

Participants received HIV prevention counselling. HIV testing was offered, but was not requested as a study prerequisite. Participants were advised to abstain from sexual intercourse until the wound was completely healed and for at least 4 weeks after the circumcision.

\section{Intervention}

All circumcisions were performed in a dedicated minor surgery room at the Catholic University of Mozambique teaching clinic. Two doctors performed each circumcision: a faculty member - highly experienced in circumcision - and a recent medical graduate with basic surgical skills. As junior team members became more skilled, they performed more of the procedure with assistance from the senior doctor. An average of 5 - 7 circumcisions per session were performed thrice weekly over a 3-month period. Our sample size gave us $>95 \%$ power to detect a mean difference of $8 \mathrm{~min}$ in the duration of surgery.

Local anaesthesia (2\% lidocaine as a subcutaneous ring block at the base of the penis) was provided as per the WHO manual. ${ }^{[7]}$

One of the following interventions was performed:

- Open surgical technique. The dorsal slit technique under local anaesthesia was used as described in the WHO manual..$^{[7]}$ After suturing, the wound was covered with an absorbent gauze dressing.

- Gomco circumcision clamp with cyanoacrylate skin adhesive. The Gomco clamp is a metal, sterilisable instrument, available in sizes from infant to adult. Four diameters were used for this study: $2.6 \mathrm{~cm}$, $2.9 \mathrm{~cm}, 3.2 \mathrm{~cm}$ and $3.5 \mathrm{~cm}$. The clamp was applied to the penis and after a period of $5 \mathrm{~min}$ the foreskin was excised with a surgical scalpel. The instrument was then removed and the apposed skin-mucosal edges sealed with high viscosity 2-octyl cyanoacrylate skin adhesive.
The wound was covered with an adherent tape or absorbent gauze. The participant was instructed to remove the absorbent gauze the following day and to keep the wound dry for the first week.

All men were observed for $20 \mathrm{~min}$ after the procedure. Subjects were given written post-operative instructions and the cellular telephone contact information of the doctor.

A video of the procedure can be found online (http://www. youtube. $\mathrm{com} /$ watch?v=0kGAsG5kFBY).

\section{Outcome measures}

- Primary. Intraoperative time.

- Secondary. Doctor-described ease in performing the technique, operative and post-operative complications, post-operative pain, time to healing, patient satisfaction, cosmetic result and direct costs of expendable materials.

- Key adverse events considered were anaesthetic complications, bleeding, haematoma, infection, wound disruption, problems with urination, subsequent procedures conducted to correct complications and occupational exposure to blood and body fluids. Standardised definitions were used to grade adverse events as mild, moderate or severe using the WHO Framework for Clinical Evaluation of Devices for Adult Male Circumcision (2009). ${ }^{[1]}$ In brief, adverse events were categorised as mild if they required little or no intervention (e.g. mild wound disruption or slight bleeding), moderate if they required active treatment (e.g. antibiotics or suturing) or severe if they required transfusion or hospitalisation or resulted in permanent damage.

- Costs. Direct costs of expendable material.

Outcome definitions are detailed in Table 1. Wound-healing outcomes were primarily assessed by the principal investigator, but two other investigators assessed wounds in his absence. An interrater reliability analysis, comparing the wound assessments of the two primary assessors, was undertaken.

Table 1. Outcome definitions

\begin{tabular}{|c|c|}
\hline Endpoint & Definition \\
\hline Operating time & Time from first clamp on foreskin until dressing placed \\
\hline Pain assessment using VAS $(0-10)$ & Self-reported pain during first 24 and 48 hours \\
\hline Blood loss (ml) & Quantity estimated by senior surgeon \\
\hline Adverse event & $\begin{array}{l}\text { - Mild: no active intervention other than wound pressure for bleeding } \\
\text { - Moderate: medical intervention (sutures, antibiotics) } \\
\text { - Severe: transfusion, hospitalisation or resulted in permanent disfigurement }\end{array}$ \\
\hline Wound infection & $\begin{array}{l}\text { Empirical diagnosis based on wound swelling, redness and pain. No bacterial cultures were } \\
\text { available. }\end{array}$ \\
\hline Wound disruption & Length of wound disruption or granulation tissue $(<2 \mathrm{~cm} \mathrm{v.}>2 \mathrm{~cm})$ \\
\hline Wound fully healed & Completely epithelialised; no superficial ulcerations or granulation tissue present \\
\hline Cosmetic appearance & $\begin{array}{l}\text { Regular: scar line straight without any irregularity } \\
\text { Irregular: Some irregularity to scar line } \\
\text { Scalloped: wavy appearance to scar line }\end{array}$ \\
\hline Participant satisfaction* & $\begin{array}{l}\text { 'Are you satisfied with your circumcision result? If not, why not?' } \\
\text { 'Would you recommend circumcision to friends or relatives?' }\end{array}$ \\
\hline $\begin{array}{l}\text { Doctor's perception of ease of } \\
\text { performance* }\end{array}$ & 'How easy is the Gomco procedure compared to the open surgical procedure?' \\
\hline Doctor's recommendation ${ }^{*}$ & 'Which circumcision method would you recommend?' \\
\hline
\end{tabular}




\section{Follow-up}

Follow-up examination occurred at 2 days, 7 days, 2 weeks, and 4 weeks. For those men who were not completely healed by 4 weeks an additional 6-week follow-up visit was conducted.

\section{Data analysis}

We collected data from participants on socio-demographics and circumcision knowledge/attitudes, and from participating doctors on ease of performing the surgery. A 10-point visual analogue scale was used for pain evaluation in the first 48 hours after circumcision and we used a 5-point Likert scale to grade satisfaction.

We conducted analysis of baseline data to examine potential confounders, calculated the descriptive statistics of outcomes and performed statistical tests of operative time, differences in scale (e.g. 5-point Likert and 10-point pain scale) and proportions. Data were analysed with Epi Info (version 7).

\section{Study changes}

Use of prophylactic antibiotics and type of wound dressing were not specified in the study protocol. Given frequent wound infections, a single dose of pre-operative oral cloxacillin as prophylaxis was introduced after the first 72 participants. An adherent tape (Hypafix, Smith \& Nephew, USA) over the tissue adhesive was used for the first 41 Gomco clamp circumcisions, but was subsequently discontinued because it trapped moisture and led to premature adhesive failure.

\section{Pilot study}

The study was started using inexpensive generic Gomco instruments. However, these instruments failed to consistently fuse the mucosal-skin layers and subsequently Gomco-branded instruments were employed. The first 55 subjects (28 Gomco and 27 surgical) were regarded as comprising the pilot phase; 6/28 (21\%) Gomco pilotphase participants required intraoperative suturing. The results of this pilot study can be accessed online (https://docs.google.com/ file/d/0B5NKq1ox1d37ejNTNDNfcGFSNjg/ edit?usp=sharing).

\section{Results \\ Participant flow}

The flow of participants in the study is shown in Fig. 1. Participants were recruited between 30 October 2012 and 2 February 2013. A total of 241 men were interviewed and $200(83 \%)$ participated in the study. All participants were circumcised using the method to which they were randomly allocated.

\section{Baseline data}

Baseline characteristics of the participants are shown in Table 2. There were no significant differences between the two groups.

\section{Outcomes analysed}

Operative outcomes are shown in Table 3. There were no intraoperative complications and none of the Gomco circumcisions required intraoperative suturing. Intraoperative time and blood loss (without frenulectomy) were less with the Gomco/tissue adhesive technique (12.8 $\mathrm{min}$ v. $22.5 \mathrm{~min} ; p<0.001$ and $1.2 \mathrm{ml} \mathrm{v.} 4.7$ $\mathrm{ml} ; p<0.001$; respectively).

Adverse events are shown in Table 4. There was no significant difference between the two groups in terms of bleeding, haematoma or infection, either taken individually or as a composite. The rate of wound infection was $6.9 \%$ prior to the use of prophylactic antibiotics and $1.4 \%$ after initiation of cloxacillin prophylaxis. Wound disruptions $>2 \mathrm{~cm}$ occurred in $1 \%$ of the Gomco circumcisions at 2 days, $10.1 \%$ at 1 week, and $20.8 \%$ at 2 weeks. Wound disruptions were not more than $5 \mathrm{~mm}$ in width, and none required surgical closure. The rate of $>2 \mathrm{~cm}$ wound length disruption was $24.4 \%$ using adherent dressing (Hypafix) and $18.2 \%$ after it was discontinued.
Post-operative pain, healing time, partici- pant satisfaction and cosmetic results are shown in Table 5. Pain scores were low and there was less pain in the Gomco group during the first 48 hours ( 1.8 v. 2.5 on a 10 -point scale; $p=0.008$ ). There were no differences in healing at 4 weeks or in patient satisfaction. The cosmetic result was superior in the Gomco group, a regular scar line developing in $98.9 \%$ v. $58.5 \%$ $(p<0.001)$ of patients.

\section{Cost of expendable material}

The retail price per single-use tube of tissue adhesive was US\$21. Two 3-0 Chromic sutures for each surgical procedure were used at a retail price of US $\$ 3.25$ each. Other costs (e.g. local anaesthesia, bandages) were identical for the two methods.

Inter-rater reliability analysis showed $97.5 \%$ agreement between the two raters ( $\kappa=95 \%)$.

The results from the doctors' survey are shown in Table 6. Doctors found the Gomco procedure easier to perform and recommended it over the open surgical technique. There were five glove perforations during the study.

\section{Discussion}

The challenge for areas with high HIV prevalence is to provide safe and cost-effective

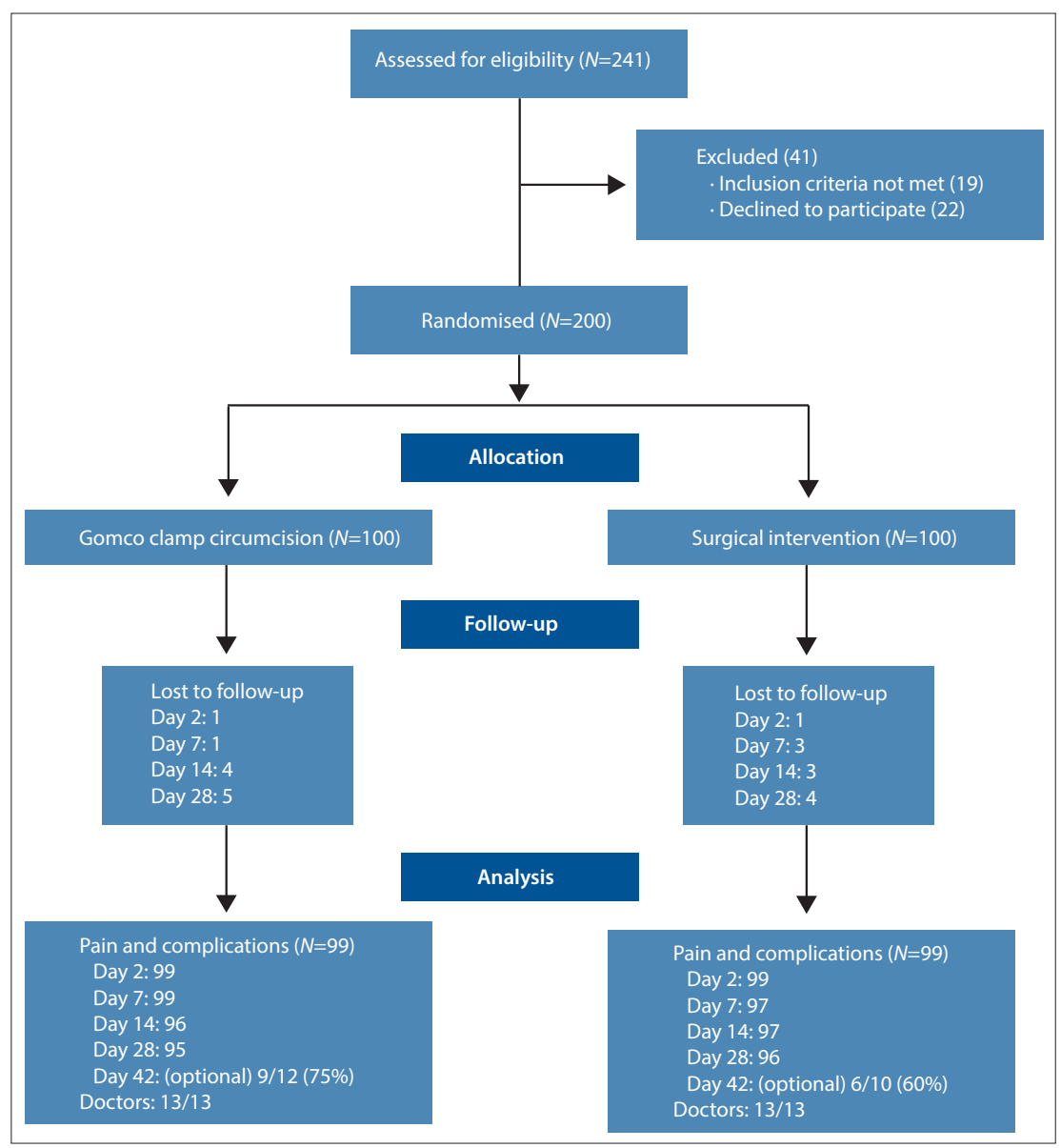

Fig. 1. Study sample inclusion flow diagram. 
VMMC in resource-limited settings. Scaleup has been constrained by the technical difficulties of performing open surgical circumcision, the only method approved by PEPFAR. In order to more effectively scaleup services, fundamental improvements in current circumcision techniques are required. The key is to have surgical techniques that are rapid, easy to learn, can be performed with

Table 2. Baseline characteristics of each group ${ }^{*}$

\begin{tabular}{|c|c|c|}
\hline & \multicolumn{2}{|c|}{$n$ and $\%$} \\
\hline & Gomco/adhesive $(N=100)$ & Open surgical $(N=100)$ \\
\hline \multicolumn{3}{|l|}{ Age range (yrs) } \\
\hline $18-20$ & 49 & 43 \\
\hline $21-24$ & 27 & 26 \\
\hline$>25$ & 24 & 31 \\
\hline \multicolumn{3}{|l|}{ Marital status } \\
\hline Single (in a relationship) & 71 & 72 \\
\hline Married & 3 & 1 \\
\hline No partner & 26 & 27 \\
\hline \multicolumn{3}{|l|}{ Religion } \\
\hline Catholic & 45 & 37 \\
\hline Muslim & 6 & 6 \\
\hline Protestant & 39 & 47 \\
\hline Other & 4 & 2 \\
\hline \multicolumn{3}{|l|}{ Education level } \\
\hline None & 1 & 1 \\
\hline Primary & 18 & 14 \\
\hline Secondary & 62 & 59 \\
\hline Post-secondary & 19 & 26 \\
\hline Total (years), median & 11.5 & 12 \\
\hline \multicolumn{3}{|c|}{ Reason for wanting circumcision } \\
\hline Hygiene & 54 & 52 \\
\hline Reduce infections & 39 & 44 \\
\hline Other & 7 & 4 \\
\hline
\end{tabular}

Table 3. Intraoperative outcomes

\begin{tabular}{lll}
\hline & Gomco/adhesive $(N=100)$ & Open surgical $(N=100)$ \\
\hline $\begin{array}{l}\text { Intraoperative complication, } n \\
\text { Frenulectomy performed, } n\end{array}$ & 0 & 0 \\
$\begin{array}{l}\text { Intraoperative time (min), } \\
\text { mean } \pm \text { SD }\end{array}$ & & 19 \\
$\quad$ With frenulectomy & $21.4 \pm 5.8$ & $22.4 \pm 5.7$ \\
$\quad$ Without frenulectomy, $p<0.001$ & $12.8 \pm 2.7$ & $22.5 \pm 6.6$ \\
$\begin{array}{l}\text { Estimated blood loss (ml), } \\
\text { mean } \pm \text { SD }\end{array}$ & & \\
With frenulectomy & $3.8 \pm 2.7$ & $4.7 \pm 2.3$ \\
Without frenulectomy, $p<0.001$ & $1.2 \pm 1.2$ & $4.7 \pm 1.6$
\end{tabular}

had much better cosmetic results and was potentially safer. The time-saving and ease of this technique have important implications for VMMC scale-up in SSA.

The Gomco instrument is the leading instrument for medical neonatal circumcision in the USA, where over 1 million newborns are circumcised each year. ${ }^{[12]}$ The fact that the Gomco instrument has 'an impeccable safety record' in this setting ${ }^{[12]}$ attests to the simplicity of learning to use the instrument. While there are very few complications from the Gomco method, mismatching of parts from different-sized instruments or different manufacturers may cause tearing of tissue.

Ironically, the Gomco instrument has been approved by the US Food and Drug Administration (FDA), marketed and used since 1935 (Fig. 2), but there are no published randomised controlled trials in adults comparing it to other methods of circumcision. One paediatric study combined Gomco instrument circumcision with tissue adhesive in 48 boys ${ }^{[13]}$ but other studies used freehand circumcision with $\mathrm{CO} 2$ laser or diathermy, which are not generally available in resource-limited settings. Small case series have used the Gomco instrument and adhesive in adults, ${ }^{[14]}$ but this study constitutes the first randomised controlled trial.

A team of two physicians - one a highly experienced doctor and one a recent medical graduate - performed each circumcision done in our study. Most physicians preferred the Gomco technique and recommended it over the open surgical technique. Operative times that were slightly longer than reported in other studies of open surgical circumcision reflect the teaching environment in which the study was conducted. ${ }^{[9]}$

There were no serious adverse events in this study. Rates of mild and moderate adverse events (bleeding, haematoma and infection) were not significantly different using the two methods and were comparable to those from other studies using open surgical techniques and tissue adhesive. ${ }^{[15]}$ The main disadvantage that was encountered with the use of tissue adhesive was moderate $(>2 \mathrm{~cm})$ wound disruption that occurred in 1 (1\%) participant at 2 days, $10(10.1 \%)$ participants at 1 week and in $20(20.8 \%)$ participants at 2 weeks. Wound separation generally occurred only after the adhesive sloughed at days 5 - 10 . Wound edges were never $>5 \mathrm{~mm}$ apart and none required suturing; $87.4 \%$ were fully healed by 4 weeks and the final cosmetic result was better with the Gomco technique regardless of prior wound separation. Wound disruption was most common when the wound was not kept dry, so that when the skin became wet and macerated the adhesive lifted prior to the 
Table 4. Adverse events ${ }^{\star}$

\begin{tabular}{|c|c|c|c|}
\hline & \multicolumn{2}{|c|}{$n(\%)$} & \multirow[b]{2}{*}{$p$-value } \\
\hline & $\begin{array}{l}\text { Gomco/adhesive } \\
(N=100)\end{array}$ & $\begin{array}{l}\text { Open surgical } \\
(N=100)\end{array}$ & \\
\hline Serious post-operative complication & 0 & 0 & - \\
\hline \multicolumn{4}{|l|}{ Post-operative bleeding } \\
\hline Mild & 4 & 0 & 0.13 \\
\hline Moderate (sutured) & 6 & 1 & 0.12 \\
\hline Haematoma & 1 & 3 & 0.61 \\
\hline $\begin{array}{l}\text { Post-operative infection (antibiotic } \\
\text { required) }\end{array}$ & 7 & 3 & 0.33 \\
\hline \multicolumn{4}{|l|}{$\begin{array}{l}\text { Wound disruption at } 2 \text { days } \\
\text { (cm length) }\end{array}$} \\
\hline$<2$ & 4/99 (4) & 0 & 0.13 \\
\hline$>2$ & $1 / 99(1)$ & 0 & 1 \\
\hline \multicolumn{4}{|l|}{$\begin{array}{l}\text { Wound disruption at } 1 \text { week } \\
\text { (cm length) }\end{array}$} \\
\hline$<2$ & $10 / 99(10.1)$ & $2 / 97(2.1)$ & 0.04 \\
\hline$>2$ & $10 / 99(10.1)$ & $2 / 97(2.1)$ & 0.04 \\
\hline \multicolumn{4}{|l|}{$\begin{array}{l}\text { Wound disruption at } 2 \text { weeks } \\
\text { (cm length) }\end{array}$} \\
\hline$<2$ & $19 / 96(19.8)$ & $3 / 97(3.1)$ & $<0.001$ \\
\hline$>2$ & $20 / 96(20.8)$ & $4 / 97(4.1)$ & $<0.001$ \\
\hline
\end{tabular}

Table 5. Post-operative outcomes

\begin{tabular}{|c|c|c|c|}
\hline & $\begin{array}{l}\text { Gomco/adhesive } \\
(N=100)\end{array}$ & $\begin{array}{l}\text { Open surgical } \\
(N=100)\end{array}$ & $p$-value \\
\hline \multicolumn{4}{|l|}{ Pain (10-point scale), mean \pm SD } \\
\hline In first 24 hours & $3.3 \pm 2.7$ & $3.3 \pm 2.4$ & 0.91 \\
\hline In first 48 hours & $1.8 \pm 1.6$ & $2.5 \pm 1.9$ & 0.008 \\
\hline \multicolumn{4}{|l|}{ Wound fully healed, $n(\%)$} \\
\hline At 2 weeks & $9 / 96(9.4)$ & $2 / 97(2.1)$ & 0.06 \\
\hline At 4 weeks & $83 / 95(87.4)$ & $86 / 96(87.8)$ & 0.94 \\
\hline At 6 weeks & $92 / 92(100)$ & $91 / 92(98.9)$ & 1 \\
\hline Sexually active at 4 weeks, $n(\%)$ & $6 / 96(6.3)$ & $7 / 99(7.1)$ & 0.95 \\
\hline \multicolumn{4}{|l|}{ Satisfaction, $n(\%)$} \\
\hline Very satisfied & $56 / 95(58.9)$ & $70 / 99(70.7)$ & 0.09 \\
\hline Satisfied & $39 / 95(41.1)$ & 29/99 (29.3) & 0.09 \\
\hline Not satisfied & 0 & 0 & \\
\hline \multicolumn{4}{|l|}{ Recommendation, $n$ (\%) } \\
\hline Recommend highly & $67 / 96(69.8)$ & $64 / 99(64.6)$ & 0.44 \\
\hline Recommend & $29 / 96(30.2)$ & $35 / 99(35.4)$ & 0.44 \\
\hline Not recommend & 0 & 0 & \\
\hline \multicolumn{4}{|l|}{ Cosmetic results, $n(\%)$} \\
\hline Regular & 93/94 (98.9) & $54 / 93(58.1)$ & $<0.001$ \\
\hline Irregular & $1 / 94(1.1)$ & $35 / 93(37.6)$ & \\
\hline Scalloped & 0 & $4 / 93(4.3)$ & \\
\hline
\end{tabular}

wound acquiring sufficient tensile strength This was exacerbated by the hot, rainy summer weather when our study was conducted.

Randomised controlled trials in boys showed very low rates of wound disruption with tissue adhesive. A systematic review of circumcision in boys shows that tissue adhesive in circumcision reduces operative time, improves the cosmetic result and increases patient satisfaction when compared with sutures and was not associated with an ncrease in wound dehiscence. ${ }^{[16]}$ However, tissue adhesive closure in general surgery has a somewhat higher wound dehiscence rate compared with sutures. ${ }^{[17]}$

Tiwari et al ${ }^{[18]}$ showed a wound disruption rate of $6.8 \%$ (3/44) in boys and men (mean age 31 years) using tissue adhesive, while other case series including both men and boys found a very low rate of wound disruption. ${ }^{[14]}$ However, these case series were small and follow-up rates were not clearly stated. Some authors have cautioned against using tissue adhesive in adult circumcision because erections put tension on the wound, which could lead to dehiscence. We are not familiar with comparative studies in boys v. adults, but think it unlikely that an actively growing boy's erection would put less tension on the wound than would a man's erection.

We used high viscosity 2-octyl cyanoacrylate because it was easy to apply, and small studies have not shown differences in the performance of various formulations of cyanoacrylates. In future studies, it would be worthwhile to compare the performance of other cyanoacrylate formulations and to investigate wound reinforcement with flexible, permeable tape (like Hypafix) in drier climates.

Due to the higher cost of tissue adhesive compared to suture, the cost of expendable materials was higher using the Gomco technique, but much less expensive Asianmanufactured adhesives are available. The time savings associated with the Gomco technique are likely to substantially reduce overall cost and assist in mass scale-up. ${ }^{[19]}$ In mass circumcision settings, use of the Gomco instrument could increase productivity more than is indicated by the time advantage to perform the procedure. It takes $1-2 \mathrm{~min}$ to place the Gomco instrument, and 2 - 3 min to remove it and apply the adhesive. The 5 min of waiting time while the instrument fuses the skin-mucosal layers could be used to circumcise other men in an assemblyline fashion, further improving productivity. Throughput would more than double using this technique, and the ease of performance and minimal intraoperative blood loss would reduce stress among staff members. 
A further advantage of the Gomco/tissue adhesive technique is that once the simple technique is mastered, it can be performed identically in all age groups from newborn to adult. Infant circumcision needs to be preceded by lysis of adhesions, making the procedure more technically difficult than in older age groups, but it requires neither suture nor adhesive in the first two months of life. Gomco instruments come in sizes from newborn to pre-adolescents $(1.1,1.3$, $1.45,1.6,1.8$ and $2.1 \mathrm{~cm}$ ), as well as the four adult sizes used in this study. Our clinical experience is consistent with published studies in suggesting that Gomco and adhesive is also an ideal method for pre- adolescent boys.

There were five glove perforations among doctors during the study. However, because the Gomco/tissue adhesive procedure requires no sutures, there is no possibility of a needle-stick injury from a suture needle.

No one technique will be suitable for all settings. The Gomco/tissue adhesive procedure is ideal for outpatient settings, where large numbers of circumcisions are performed by mid-level staff, or for use by private practitioners who have basic surgical skills and wish to add circumcision services to their practice. Because of the risk of postoperative bleeding, the procedure is not suitable for rural clinics lacking a provider skilled in haemostasis and suturing.

Generic Gomco instruments are widely available online for $<$ US $\$ 20$, but were abandoned when they failed to consistently fuse the mucosal-skin excision line. The Gomco-branded instruments we used cost $\sim$ US $\$ 200$ each, but several of them were misaligned. We believe that the poor quality of the Gomco clamps was responsible for most of the post-operative bleeding episodes and have reported this to the FDA.

This study was non-blinded and was performed at a single centre. The wound healing outcomes were primarily assessed by the principal investigator, but also by two other assessors after training. An inter-rater reliability analysis showed a high concordance between the two principal raters, but there was no independent, objective measure of wound healing outcomes.

There is interest in the use of plastic rings (Ali's clamp, Shang Ring, PrePex device, and others), ${ }^{[20,21]}$ which are left in situ until they are removed at a 1-week clinic visit. They are rapid and simple to place, safe and have been approved or are pending approval in many key countries. However, the time advantages in placing the device are counterbalanced by the logistics of a return visit for device removal, the unpleasantness of wearing the device and the smell of necrotic material for one week, and healing by secondary intention which delays wound closure. Initiation of sexual activity prior to full healing may lead to increased transmission of sexually transmitted diseases. Back-up surgical services are also needed for Shang Ring placement failures. Unlike the Prepex device, the Gomco instrument can be used in men with phimosis; other abnormalities such as tight frenulum can also easily be corrected at the time of surgery.

Plastic, disposable Gomco-like instruments can now be produced without infringement of design rights. Given the difficulty of sterilising instruments in resource-limited settings, it should be an important research priority to develop and evaluate disposable Gomcolike instruments for safety and efficacy. Prepackaged disposable instruments would also obviate the possibility of mismatching of parts.

\section{Conclusion}

Removing the foreskin with the Gomco instrument and sealing the wound with cyanoacrylate tissue adhesive in adults is quicker, easier to perform, and potentially safer than open surgical circumcision. Compared to suturing, use of tissue adhesive does result in higher rates of wound disruption at 7 and 14 days, but does not require treatment and has better cosmetic results. This method can greatly facilitate scale-up of mass circumcision programmes. A disposable plastic, Gomcolike device should be produced and evaluated for use in resource-limited settings.

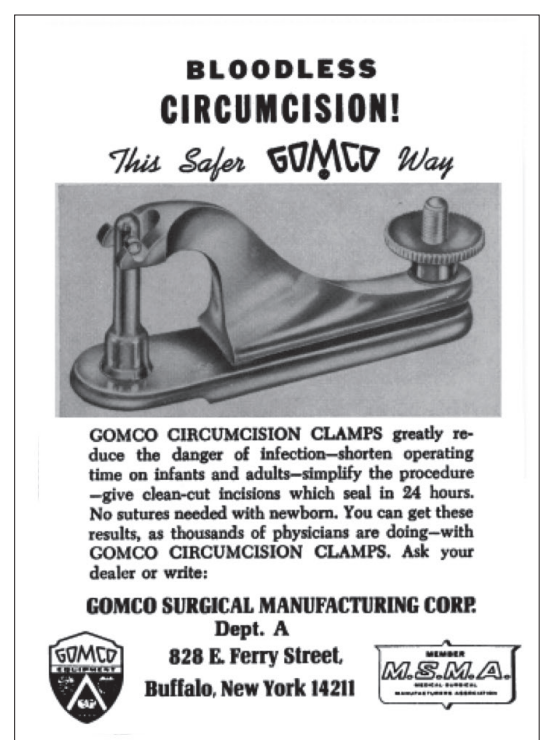

Fig. 2. Advertisement for the Gomco clamp (Can Med Assoc J, 1970).

Table 6. Doctors' survey

\begin{tabular}{lll} 
Table 6. Doctors' survey & Senior physicians $(\mathbf{N}=\mathbf{4})$ & Junior physicians $(\mathbf{N = 9})$ \\
\hline $\begin{array}{l}\text { Circumcisions performed prior to } \\
\text { study, median (range) }\end{array}$ & & \\
$\quad$ Surgical & $575(300-1000)$ & $2(0-50)$ \\
Gomco clamp & $0(0-1000)$ & $3(0-50)$ \\
Ease of performance, $n(\%)$ & & $1(11)$ \\
Gomco much easier & $1(25)$ & $8(89)$ \\
Gomco easier & $1(25)$ & 0 \\
Neutral & $2(50)$ & 0 \\
Surgical easier & 0 & 0 \\
Surgical much easier & 0 & \\
Method of preference, $n(\%)$ & & $2(22)$ \\
Strongly prefer Gomco & $2(50)$ & $4(44)$ \\
Prefer Gomco & 0 & $2(22)$ \\
Neutral & 0 & 0 \\
Prefer surgical & $1(25)^{*}$ & $1(11)$ \\
Strongly prefer surgical & $1(25)$ & \\
Glove perforations during the study, $n$ & & 6 \\
0 & 3 & 2 \\
1 & 1 &
\end{tabular}




\section{RESEARCH}

Acknowledgements. We thank Dr Deborah McMahon and Dr Lee Harrison for participating in the Data Monitoring Committee; Lydia Shedlofsky, Alison Cobianchi and Luis Augusto Joaquinho for participating in data collection and management; and Dr Pablo Vega and Dr Carlos Bras Silva and our other esteemed colleagues at the Catholic University of Mozambique who performed the circumcisions.

Funding. This study was funded by the Catholic University of Mozambique and by a Fogarty International Center, National Institutes of Health grant (no. 3 D43 TW01038) to the University of Pittsburgh. No funding bodies played any role in the design, writing, or decision to publish this manuscript.

\section{References}

1. Siegfried N, Muller M, Deeks JJ, Volmink J. Male circumcision for prevention of heterosexual aquisition of HIV in men. Cochrane Database Syst Rev 2009:CD003362. [http://dx.doi. org/10.1002/14651858.CD003362.pub2

2. Centers for Disease Control and Prevention. Progress in voluntary medical male circumcision service provision - Kenya, 2008-2011. MMWR Morb Mortal Wkly Rep 2012;61(47):957-961. http://www.cdc. $\mathrm{gov} / \mathrm{mmwr} / \mathrm{preview} / \mathrm{mmwrhtml} / \mathrm{mm} 6147 \mathrm{a} 2 . \mathrm{htm}$ (accessed 31 May 2013).

3. Reed JB, Njeuhmeli E, Thomas AG, et al.Voluntary medical male circumcision: An HIV prevention priority for PEPFAR. J Acquir Immune Defic Syndr 2012;60:S88-S95. [http://dx.doi.org/10.1097/ QAI.0b013e31825cac4e]

4. Hallett TB, Singh K, Smith JA, White RG, Abu-Raddad LJ, Garnett GP. Understanding the impact of male circumcision interventions on the spread of HIV in southern Africa. PLoS One 2008;3(5):e2212. http://dx.doi.org/10.1371/journal.pone.0002212]

5HO, UNAIDS. Joint Strategic Action Framework to Accelerate the Scale-up of Voluntary Medical Male Circumcision for HIV Prevention in Eastern and Southern Africa, 2012-2016. Geneva: WHO, 2011. http://www.who.int/hiv/pub/strategic_action2012_2016/en/index.html (accessed 31 May 2013). American Academy of Pediatrics. Task Force on Circumcision. Pediatrics. 2012;130(3):e756-e785. [http://dx.doi.org/10.1542/peds.2012-1990]

WHO. Manual for Male Circumcision Under Local Anaesthesia. Geneva: WHO, 2009. http://www. who.int/hiv/pub/malecircumcision/who_mc_local_anaesthesia.pdf (accessed 31 May 2013).

8. Bailey RC, Egesah O, Rosenberg S. Male circumcision for HIV prevention: A prospective study of complications in clinical and traditional settings in Bungoma, Kenya. Bull World Health Organ 2008;86(9):669-677. [http://dx.doi.org/10.2471/BLT.08.051482]
9. Herman-Roloff A, Bailey RC, Agot K. Factors associated with the safety of voluntary medical male circumcision in Nyanza province, Kenya. Bull World Health Organ. 2012;90:773-781. [http://dx.do org $/ 10.2471 /$ BLT.12.106112

10. Kim HH, Goldstein M. High complication rates challenge the implementation of male circumcision for HIV prevention in Africa. Nat Clin Pract Urol 2009;6(2):64-65. [http://dx.doi org/10.1038/ncpuro1279

11. WHO. Framework for Clinical Evaluation of Devices for Adult Male Circumcision. Geneva: WHO, 2011 http://apps.who.int/iris/bitstream/10665/75954/1/9789241504355_eng.pdf (accessed 31 May 2013).

12. WHO. Manual for Early Infant Male Circumcision Under Local Anaesthesia. Geneva: WHO, 2010 http://whqlibdoc.who.int/publications/2010/9789241500753_eng.pdf (accessed 31 May 2013).

13. Elmore JM, Smith EA, Kirsch AJ. Sutureless circumcision using 2-octylcyanoacrylate (Dermabond): Appraisal after 18-month experience. Urology 2007;70(4):803-806. [http://dx.doi.org/10.1016/j.

14. O'Sullivan JB, Shabbir J, Masokwane P, Byrnes G. The benefits of histoacryl tissue glue over sutures for wound approximation after circumcision with Gomco clamp. Irish J Med Sci 2002;171(2):57-58 [http://dx.doi.org/10.1007/BF03170099]

15. Kelly BD, Lundon DJ, Timlin ME, et al. Paediatric sutureless circumcision - an alternative to the standard technique. Pediatr Surg Int 2012;28(3):305-308. [http://dx.doi.org/10.1007/s00383-0113015-0]

6. Lane V, Vajda P, Subramaniam R. Paediatric sutureless circumcision: A systematic literature review. Pediatr Surg Int 2010;26(2):141-144. [http://dx.doi.org/10.1007/s00383-009-2475-y]

17. Coulthard P, Esposito M, Worthington HV, et al. Tissue adhesives for closure of surgical incisions. Cochrane Database Syst Rev 2010(5):CD004287. [http://dx.doi.org/10.1002/14651858.CD004287. pub3]

18. Tiwari P, Tiwari A, Kumar S, et al. Sutureless circumcision - an Indian experience. Indian J Urol 2011;27(4):475-478. [http://dx.doi.org/10.4103/0970-1591.91435]

19. Kaye JD, Kalisvaart JF, Cuda SP, Elmore JM, Cerwinka WH, Kirsch AJ. Sutureless and scalpel-free circumcision - more rapid, less expensive and better? J Urol 2010;184(4):1758-1762. [http://dx.doi. org/10.1016/.juro.2010.03.081]

20. Mutabazi V, Kaplan SA, Rwamasirabo E, et al. HIV prevention: Male circumcision comparison between a nonsurgical device to a surgical technique in resource-limited settings: A prospective randomized, nonmasked trial. J Acquir Immune Defic Syndr 2012;61(1):49-55. [http://dx.do org/10.1097/QAI.0b013e3182631d69

21. Barone MA, Ndede F, LiPS, et al. The Shang Ring device for adult male circumcision: A proof o concept study in Kenya. J Acquir Immune Defic Syndr 2011;57(1):e7-e12. [http://dx.doi.org/10.1097/ QAI.0b013e3182158967]

Accepted 8 May 2013. 